\title{
Directed evolution of a $\beta$-mannanase from Rhizomucor miehei to improve catalytic activity in acidic and thermophilic conditions
}

Yan-xiao Li ${ }^{1}$, Ping Yi ${ }^{1}$, Qiao-juan Yan ${ }^{1 *}$, Zhen Qin², Xue-qiang Liu' ${ }^{1}$ and Zheng-qiang Jiang ${ }^{2 *}$

\begin{abstract}
Background: $\beta$-Mannanase randomly cleaves the $\beta-1,4-$ linked mannan backbone of hemicellulose, which plays the most important role in the enzymatic degradation of mannan. Although the industrial applications of $\beta$-mannanase have tremendously expanded in recent years, the wild-type $\beta$-mannanases are still defective for some industries. The glycoside hydrolase (GH) family $5 \beta$-mannanase (RmMan5A) from Rhizomucor miehei shows many outstanding properties, such as high specific activity and hydrolysis property. However, owing to the low catalytic activity in acidic and thermophilic conditions, the application of RmMan5A to the biorefinery of mannan biomasses is severely limited.

Results: To overcome the limitation, RmMan5A was successfully engineered by directed evolution. Through two rounds of screening, a mutated $\beta$-mannanase $(\mathrm{mRmMan} 5 \mathrm{~A})$ with high catalytic activity in acidic and thermophilic conditions was obtained, and then characterized. The mutant displayed maximal activity at $\mathrm{pH} 4.5$ and $65^{\circ} \mathrm{C}$, corresponding to acidic shift of 2.5 units in optimal $\mathrm{pH}$ and increase by $10^{\circ} \mathrm{C}$ in optimal temperature. The catalytic efficiencies $\left(k_{\text {cat }} / K_{m}\right)$ of mRmMan5A towards many mannan substrates were enhanced more than threefold in acidic and thermophilic conditions. Meanwhile, the high specific activity and excellent hydrolysis property of RmMan5A were inherited by the mutant mRmMan5A after directed evolution. According to the result of sequence analysis, three amino acid residues were substituted in mRmMan5A, namely Tyr233His, Lys264Met, and Asn343Ser. To identify the function of each substitution, four site-directed mutations (Tyr233His, Lys264Met, Asn343Ser, and Tyr233His/Lys264Met) were subsequently generated, and the substitutions at Tyr233 and Lys264 were found to be the main reason for the changes of mRmMan5A.

Conclusions: Through directed evolution of RmMan5A, two key amino acid residues that controlled its catalytic efficiency under acidic and thermophilic conditions were identified. Information about the structure-function relationship of GH family $5 \beta$-mannanase was acquired, which could be used for modifying $\beta$-mannanases to enhance the feasibility in industrial application, especially in biorefinery process. This is the first report on a $\beta$-mannanase from zygomycete engineered by directed evolution.
\end{abstract}

Keywords: Directed evolution, Rhizomucor miehei, $\beta$-Mannanase, Acidic pH, Optimal temperature, Biorefinery

\section{Background}

As the huge consumption of fossil fuels results in enormous emission of greenhouse gases, more and more

\footnotetext{
*Correspondence: yanqj@cau.edu.cn; zhqjiang@cau.edu.cn

${ }^{1}$ Beijing Advanced Innovation Center for Food Nutrition and Human Health, Bioresource Utilization Laboratory, College of Engineering, China Agricultural University, No. 17 Qinghua Donglu, Haidian District, Post Box 294, Beijing 100083, China

2 Beijing Advanced Innovation Center for Food Nutrition and Human Health, College of Food Science and Nutritional Engineering, China Agricultural University, Beijing, China
}

attention is focused on the consequent air pollution and global warming [1]. To overcome this problem, biorefinery tends to be a potential method to produce biofuel from renewable cellulose and hemicellulose, which is a green alternative to fossil fuels [2]. As one of the major constituents of hemicellulose, mannans exist in many biomasses, such as coffee ground, copra meal, palm kernel cake, and some plant gums [3]. In biorefinery process, polysaccharides in biomass should be initially degraded 
into mono- and oligosaccharides through chemical, physical, and enzymatic methods $[1,4,5]$. Distinguished from other methods, enzymatic degradation is regarded as an environmental-friendly alternative. During the enzymatic degradation of mannans, $\beta$-mannanase (EC 3.2.1.78) is the most important enzyme among several mannandegrading enzymes [6]. Thus far, the industrial applications of $\beta$-mannanases have developed rapidly in food, feed, and biorefinery industry $[3,7]$.

Based on the sequence similarities, $\beta$-mannanases belong to glycoside hydrolase (GH) families $5,26,113$, and 134 in the CAZy database (carbohydrate-active enzymes database). So far, numerous $\beta$-mannanases from bacteria $[8,9]$, fungi $[10,11]$, and actinomyces $[12,13]$ have been discovered and characterized. Most of them belong to GH families 5 and 26 [14], while only a few $\beta$-mannanases are divided into $\mathrm{GH}$ families 113 and 134 [9, 11, 12]. Moreover, the $\beta$-mannanases from GH family 5 can be classified into subfamilies $7,8,10$, and 17 [15]. In alkaline condition, $\beta$-mannanases from subfamily 8 display higher activity than subfamilies 7 and 10, which usually act at acidic and neutral $\mathrm{pH}$ [16]. Even though wild-type enzymes have various desirable properties, their biochemical properties also display many limitations, which make them not suitable for industrial applications in some cases [17]. After the pretreatments of biomass, such as acidic hydrolysis, hydrothermolysis, and steam explosion, the materials are usually tested to be acidic during biorefinery process [ 5 , $18,19]$. Although many wild-type $\beta$-mannanases exhibit the maximal activity under acidic and/or thermophilic conditions, their specific activities maintain at low levels in their optimal $\mathrm{pH}$ and temperatures $[20,21]$, causing the high cost in production and then the limitation in biorefinery industry.

To satisfy the requirement of biorefinery application, $\beta$-mannanases can be engineered to optimize its biochemical properties. One of the most successful approaches is to engineer the enzyme via directed evolution [22]. Requiring little structure information of target protein, directed evolution has been increasingly exploited to optimize the traits of enzyme, such as optimal condition, stability, and selectivity [23-25]. However, only a few reports, so far, are available to improve $\beta$-mannanase properties via directed evolution. Wang et al. [26] have engineered a GH family $26 \beta$-mannanase from Pantoea agglomerans A021, whose catalytic efficiency has increased at least 1.14-fold after directed evolution. In another study, the specific activities of two $\beta$-mannanases, belonging to $\mathrm{GH}$ families 5 and 26 from Podospora anserina, are significantly enhanced by directed evolution [27]. However, there is no information on change of the optimal conditions of $\beta$-mannanases via directed evolution yet.
Rhizomucor miehei CAU432 is a thermophilic filamentous fungus which can produce various glycoside hydrolase, such as endo- $\beta-1,3$-glucanase and lichenase [28, 29]. Its GH family $5 \beta$-mannanase (RmMan $5 \mathrm{~A}$, GenBank Accession No. AGC24277.1) has been functionally and structurally characterized in previous reports [30, 31]. $R m$ Man5A exhibits a classical $(\beta / \alpha)_{8}$-TIM barrel fold and displays many outstanding properties, e.g., high specific activity and hydrolysis property, which makes it a suitable candidate for many industrial applications. However, $R m$ Man $5 \mathrm{~A}$ shows maximal activity at neutral $\mathrm{pH}$ and $50{ }^{\circ} \mathrm{C}$, which largely limits its application in biorefinery. In this study, to enhance the catalytic activity of $R m M a n 5 A$ in acidic and thermophilic conditions and gain more information on the structure-function relationship of $\beta$-mannanase, $R m$ Man $5 \mathrm{~A}$ was engineered using errorprone polymerase chain reaction (error-prone PCR), DNA shuffling, site-directed mutagenesis (SDM), and site-saturation mutagenesis (SSM). This strategy offers a potential to remodel the $\beta$-mannanase for increasing the catalytic efficiency under acidic and thermophilic conditions while retaining its specific activity and hydrolysis property. This is the first report on $\beta$-mannanase from a zygomycete engineered by directed evolution.

\section{Results}

\section{Screening of the mutant library}

A mutant library with a mutation frequency of $0.72 \%$ was generated by error-prone PCR and DNA shuffling using the primers in Additional file 1: Table S1. The summary of two rounds of screening and the number of mutants selected at each step are shown in Additional file 1: Figure S1. During the initial step of screening, the mutant library containing 12,000 clones were pre-screened by Congo red plate. Since the variant with improved activity at acidic $\mathrm{pH}$ was expected, the $\mathrm{pH}$ of screening plate was adjusted to 5.0 with McIlvaine buffer. More than $30 \%$ of the clones formed clear spots, while only 894 clones had clear halos whose diameter could be measured. The diameter of the control halo caused by RmMan5A was about 4-5 mm. Compared to this size, only 198 clones showed similar or larger size of halos. The diameter of larger halos could reach 7-8 $\mathrm{mm}$. Subsequently, the selected clones were cultured and inducted in $50-\mathrm{mL}$ conical flasks and biochemical assays were conducted to analyze their optimal conditions. Finally, one mutant $(\mathrm{mRm}$ Man5A) was obtained, displaying high catalytic activity under acidic and thermophilic conditions. According to the results of DNA sequencing, $\mathrm{m} R m \mathrm{man} 5 \mathrm{~A}$ contained 5 base substitutions, two of which led to silent mutations (Ala261: gct-gcc, Leu318: tta-ttg), while the others led to three non-silent mutations, namely Tyr233His, Lys264Met, and Asn343Ser. Amino acid sequence alignment 
of $R m$ Man5A with the homologous $\beta$-mannanases was performed and revealed that residue Try233 was entirely conserved, Lys 264 was partly conserved, and Asn343 was non-conserved in GH family $5 \beta$-mannanases (Fig. 1).

\section{Expression and purification of protein}

The mutant $\beta$-mannanase gene (mRmMan5A) was amplified by PCR and then inserted into pET28a $(+)$ plasmid with $\mathrm{BamHI}$ and $\mathrm{XhoI}$ restriction sites. Subsequently, the mutant $\beta$-mannanase without the signal peptide was successfully expressed in Escherichia coli BL21 and purified by Ni-IDA column chromatography with a purification fold of 8.2 and a recovery yield of $67.9 \%$. Sodium dodecyl sulfate polyacrylamide gel electrophoresis (SDS-PAGE) analysis indicated that $\mathrm{mRmMan} 5 \mathrm{~A}$ migrated as a single homogeneous band of $44 \mathrm{kDa}$ (Fig. 2), which was same as RmMan5A [30].

\section{Properties and kinetic parameters}

Compared to RmMan5A, optimal $\mathrm{pH}$ of $\mathrm{m} R m \mathrm{Man} 5 \mathrm{~A}$ was 4.5 , which shifted 2.5 units towards acidic range (Fig. 3a). mRmMan5A was found to exhibit more than $80 \%$ of the maximal activity after incubation at $\mathrm{pH}$ range of 4.0-8.5 for $30 \mathrm{~min}$ (Fig. 3b). Optimal temperature of $\mathrm{m} R m$ Man5A was $65{ }^{\circ} \mathrm{C}$, which was higher than that of RmMan5A ( $\left.55^{\circ} \mathrm{C}\right)$ (Fig. 3c). mRmMan5A showed excellent thermostability up to $55{ }^{\circ} \mathrm{C}$ (Fig. 3d), indicating that $\mathrm{mRmMan} 5 \mathrm{~A}$ had inherited the thermostability of RmMan5A.

Similar to RmMan5A, mRmMan5A showed the maximal specific activity towards locust bean gum (LBG, 9671.4 $\mathrm{U} \mathrm{mg}^{-1}$ ), followed by konjac powder $\left(5633.1 \mathrm{U} \mathrm{mg}^{-1}\right)$ and guar gum $\left(1472.1 \mathrm{U} \mathrm{mg}^{-1}\right.$ ) (Table 1). The specific activities of $\mathrm{m} R m \mathrm{Man} 5 \mathrm{~A}$ were three times higher than those of $R m M a n 5 \mathrm{~A}$ at pH 4.5 and $65{ }^{\circ} \mathrm{C}$. Kinetic parameters of $\mathrm{mRmMan} 5 \mathrm{~A}$ and $R m \mathrm{Man} 5 \mathrm{~A}$ were measured with LBG and guar gum as substrates at $\mathrm{pH} 4.5$

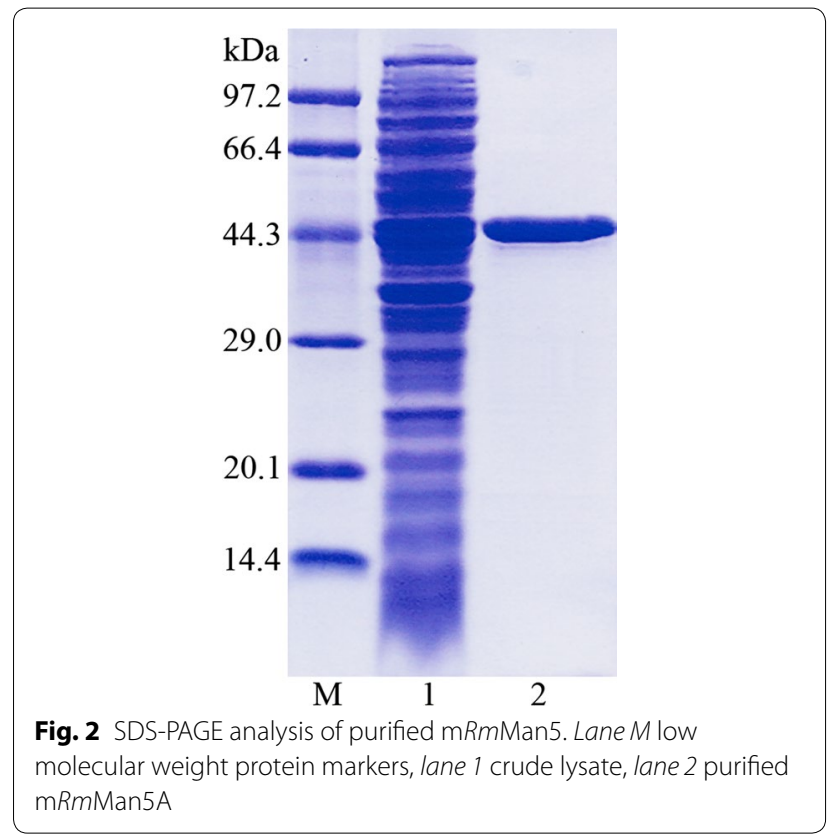

and $65{ }^{\circ} \mathrm{C}$ (Table 2). The maximal velocity $\left(V_{\max }\right)$ of $\mathrm{m} R m$ Man5A towards LBG was higher than that of $R m$ Man5A by 3.2 -fold, while the $K_{\mathrm{m}}$ value of $\mathrm{m} R m \mathrm{man} 5 \mathrm{~A}$ remained unchanged compared to RmMan5A. Moreover, the catalytic efficiency $\left(k_{\text {cat }} / K_{\mathrm{m}}\right)$ of $\mathrm{mRmMan} 5 \mathrm{~A}$ was enhanced about 3.3-fold at pH 4.5 and $65{ }^{\circ} \mathrm{C}$. Similar results were obtained when guar gum was used as substrate.

\section{Hydrolysis property}

The hydrolysis property of $\mathrm{m} R m \mathrm{Man} 5 \mathrm{~A}$ towards various manno-oligosaccharides and mannans was determined by TLC. mRmMan5A could not degrade mannobiose (M2) and mannotriose (M3), even after prolonging the incubation period to $12 \mathrm{~h}$ (Fig. 4a). However, the enzyme could rapidly cleave mannotetrose (M4) to finally yield

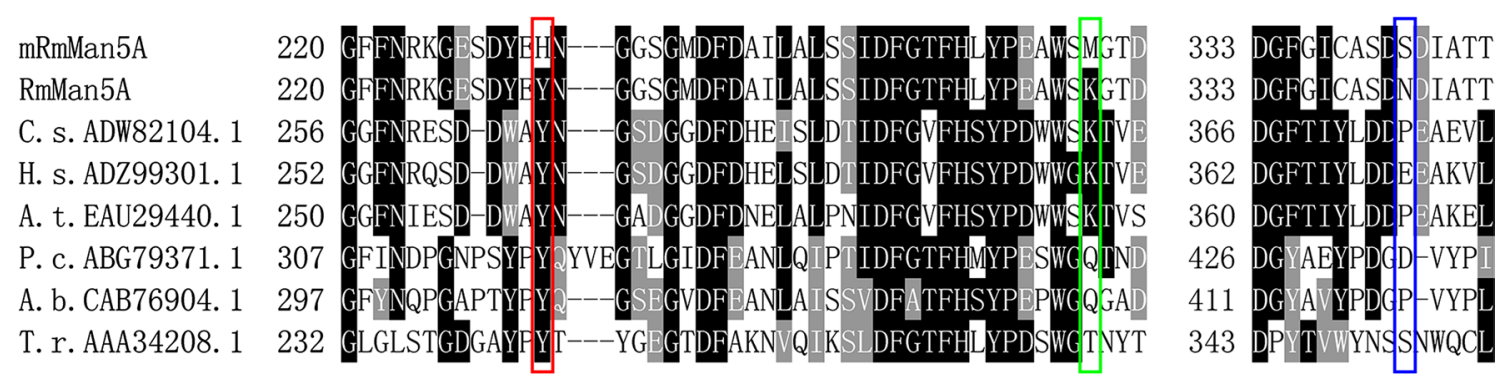

Fig. 1 Amino acid sequence similarity of mRmMan5A and RmMan5A with other GH family $5 \beta$-mannanases. Numbers on the left are the residue number of the first amino acid in each line. Sequences listed include the $\beta$-mannanases from Chaetomium sp. CQ31 (ADW82104.1), Humicola sp. Y1 (ADZ99301.1), Aspergillus terreus NIH2624 (EAU29440), Phanerochaete chrysosporium (ABG79371.1), Agaricus bisporus (CAB76904.1), and Trichoderma reesei (AAA34208.1). The single-letter amino acid code is used. Identical residues are shaded in black, and conserved residues are shaded in gray. The locations of three substitutions (Tyr233His, Lys264Met, and Asn343Ser) are boxed in red, green, and blue, respectively 


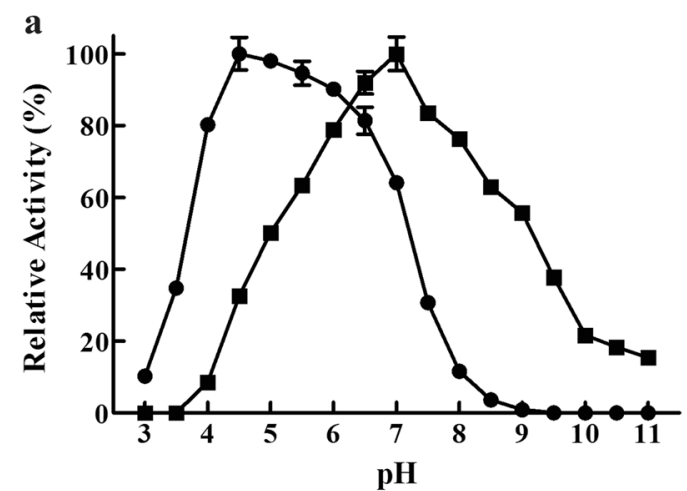

c

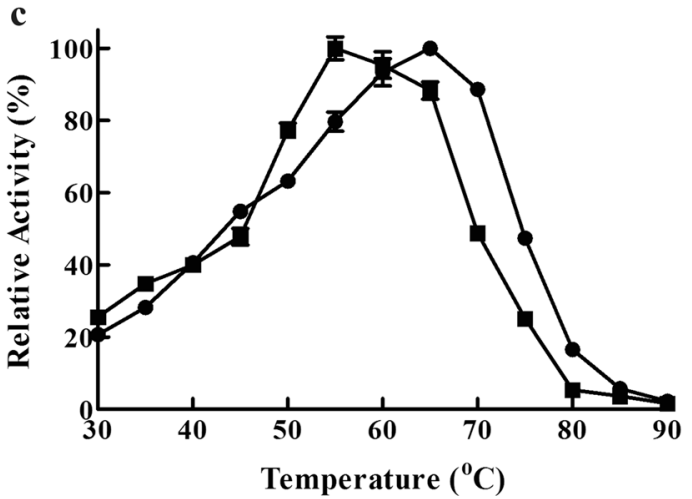

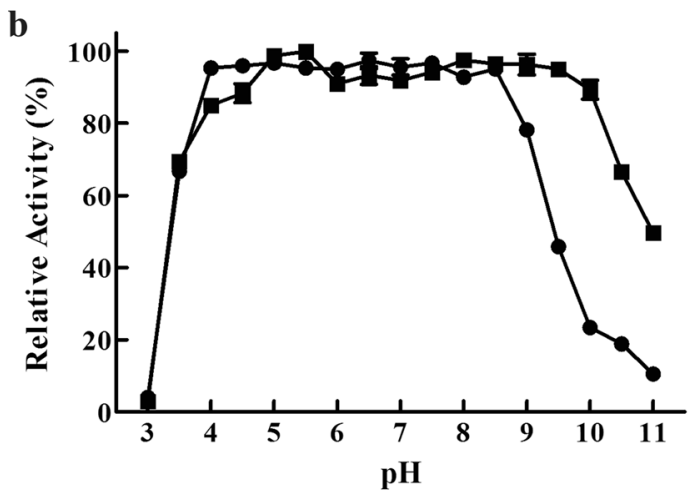

d

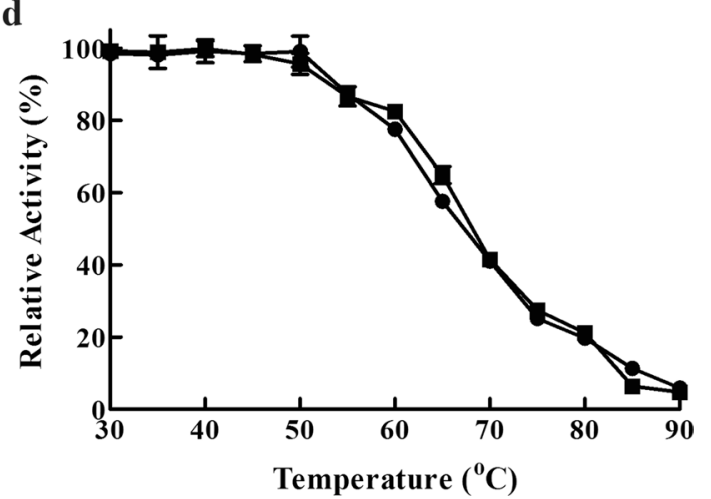

Fig. 3 Biochemical properties of RmMan5A (filled square) and mRmMan5A (filled circle). a The effect of pH on $\beta$-mannanase activity in 50 mmol $\mathrm{L}^{-1}$ different buffers at $55^{\circ} \mathrm{C}$ (for RmMan5A) or $65^{\circ} \mathrm{C}$ (for mRmMan5A). b The pH stability of each enzyme in various pH ranges. c The influence of temperature on $\beta$-mannanase activity in 50 mmol $\mathrm{L}^{-1} \mathrm{Mcllvaine}$ buffer ( $\mathrm{pH} 7.0$ for RmMan5A and pH 4.5 for mRmMan5A). d The thermostability of each enzyme at different temperatures. For $\mathrm{pH}$ stability and thermostability, the residual activities of $\mathrm{RmMan} 5 \mathrm{~A}$ were measured at $\mathrm{pH} 7.0$ and $55^{\circ} \mathrm{C}$, and those of $\mathrm{mRmMan} 5 \mathrm{~A}$ were measured at $\mathrm{pH} 4.5$ and $65^{\circ} \mathrm{C}$. The specific activities of $\mathrm{RmMan} 5 \mathrm{~A}\left(10,756.3 \mathrm{U} \mathrm{mg}^{-1}\right)$ and mRmMan5 $\mathrm{A}\left(9671.4 \mathrm{U} \mathrm{mg}{ }^{-1}\right)$ were considered as $100 \%$ to determinate the optimal pH, pH stability, optimal temperature, and thermostability

Table 1 Substrate specificity of $\mathrm{m} R \mathrm{mMan} 5 \mathrm{~A}$ and $\operatorname{RmMan5A}$

\begin{tabular}{|c|c|c|c|}
\hline \multirow[t]{3}{*}{ Substrate } & \multicolumn{3}{|c|}{ Specific activity $\left(U \mathrm{mg}^{-1} ;\right.$ mean \pm SD $)$} \\
\hline & \multirow{2}{*}{$\begin{array}{l}\mathrm{mRmMan} 5 \mathrm{~A}^{\mathrm{a}} \\
\mathrm{pH} 4.5,65^{\circ} \mathrm{C}\end{array}$} & \multicolumn{2}{|l|}{$\operatorname{RmMan} 5 \mathrm{~A}^{\mathbf{b}}$} \\
\hline & & $\mathrm{pH} 4.5,65^{\circ} \mathrm{C}$ & $\mathrm{pH} 7.0,55^{\circ} \mathrm{C}$ \\
\hline LBG & $9671.4 \pm 327$ & $3011.8 \pm 53$ & $10,756.3 \pm 424$ \\
\hline Konjac powder & $5633.1 \pm 102$ & $1382.6 \pm 28$ & $5317.6 \pm 172$ \\
\hline Guar gum & $1472.1 \pm 51$ & $402.9 \pm 5$ & $1492.1 \pm 27$ \\
\hline
\end{tabular}

${ }^{a}$ Enzymatic reactions were carried out at $65^{\circ} \mathrm{C}$ for $10 \mathrm{~min}$ in $50 \mathrm{mmol} \mathrm{L}{ }^{-1}$ Mcllvaine buffer ( $\mathrm{pH} 4.5$ )

b Enzymatic reactions were carried out at $65^{\circ} \mathrm{C}$ for $10 \mathrm{~min}$ in $50 \mathrm{mmol} \mathrm{L}^{-1}$ Mcllvaine buffer (pH 4.5) and at $55^{\circ} \mathrm{C}$ for $10 \mathrm{~min}$ in $50 \mathrm{mmol} \mathrm{L}^{-1} \mathrm{Mcllvaine} \mathrm{buffer}$ (pH 7.0), respectively

M2 and M3 (Fig. 4b). LBG was hydrolyzed by $\mathrm{mRm-}$ Man5A to yield predominantly M2, M3, and other manno-oligosaccharides with higher degree of polymerization (Fig. 4c). Due to the complexity of glucomannan in konjac powder, the hydrolysis product was a mixture containing $\mathrm{M} 2, \mathrm{M} 3$, and other unidentifiable oligosaccharides (Fig. 4d). Mannose (M) was not detected during the hydrolysis process of all substrates used.

\section{Hydrolysis of linear mannan}

To compare the hydrolysis property of $R m M a n 5 \mathrm{~A}$ and $\mathrm{m} R m$ Man5A, the $\beta$-mannanases were employed to hydrolyze $5 \%(\mathrm{w} / \mathrm{v})$ linear mannan at $\mathrm{pH} 4.5$ and $50{ }^{\circ} \mathrm{C}$. The concentration of manno-oligosaccharides was monitored during the hydrolysis (Additional file 1: Figure S2). After incubation with $\mathrm{mRmMan} 5 \mathrm{~A}$ for $24 \mathrm{~h}$, the concentration of M2 and M3 was markedly increased and reached 30.7 and $10.5 \mathrm{mg} \mathrm{mL}^{-1}$, respectively. In contrast, the hydrolysis by RmMan5A was strongly inhibited, and the concentration of M2 and M3 only reached 11.2 and $3.1 \mathrm{mg} \mathrm{mL}^{-1}$, respectively.

\section{Site-directed mutagenesis}

To identify the effect of each substitution on biochemical property, three variants with single mutation (Tyr233His, Lys264Met, and Asn343Ser) were generated using SDM. Compared to $\mathrm{RmMan} 5 \mathrm{~A}$, optimal $\mathrm{pH}$ of variants 
Table 2 Kinetic parameters of $m R m M a n 5 A$ and $R m M a n 5 A$ (mean \pm SD)

\begin{tabular}{|c|c|c|c|c|}
\hline Procedure & $V_{\max }\left(\mu \mathrm{mol} \min ^{-1} \mathrm{mg}^{-1}\right)$ & $K_{\mathrm{m}}\left(\mathrm{mg} \mathrm{mL}^{-1}\right)$ & $k_{\text {cat }}\left(\mathrm{s}^{-1}\right)$ & $k_{\text {cat }} / K_{\mathrm{m}}\left(\mathrm{mg} \mathrm{s}^{-1} \mathrm{~mL}^{-1}\right)$ \\
\hline \multicolumn{5}{|l|}{ LBG } \\
\hline mRmMan5A & $10,154.9 \pm 293$ & $3.27 \pm 0.22$ & 7446.9 & 2277.3 \\
\hline RmMan5A & $3192.5 \pm 75$ & $3.37 \pm 0.18$ & 2341.2 & 694.7 \\
\hline \multicolumn{5}{|l|}{ Guar gum } \\
\hline mRmMan5A & $1516.3 \pm 47$ & $7.06 \pm 0.42$ & 1112.0 & 157.5 \\
\hline RmMan5A & $402.9 \pm 11$ & $7.12 \pm 0.39$ & 294.8 & 41.4 \\
\hline
\end{tabular}

Enzymatic reactions were carried out in $50 \mathrm{mmol} \mathrm{L}^{-1} \mathrm{Mcllvaine} \mathrm{buffer}(\mathrm{pH} 4.5)$ at $65^{\circ} \mathrm{C}$ for 5 min using LBG or guar gum as substrate

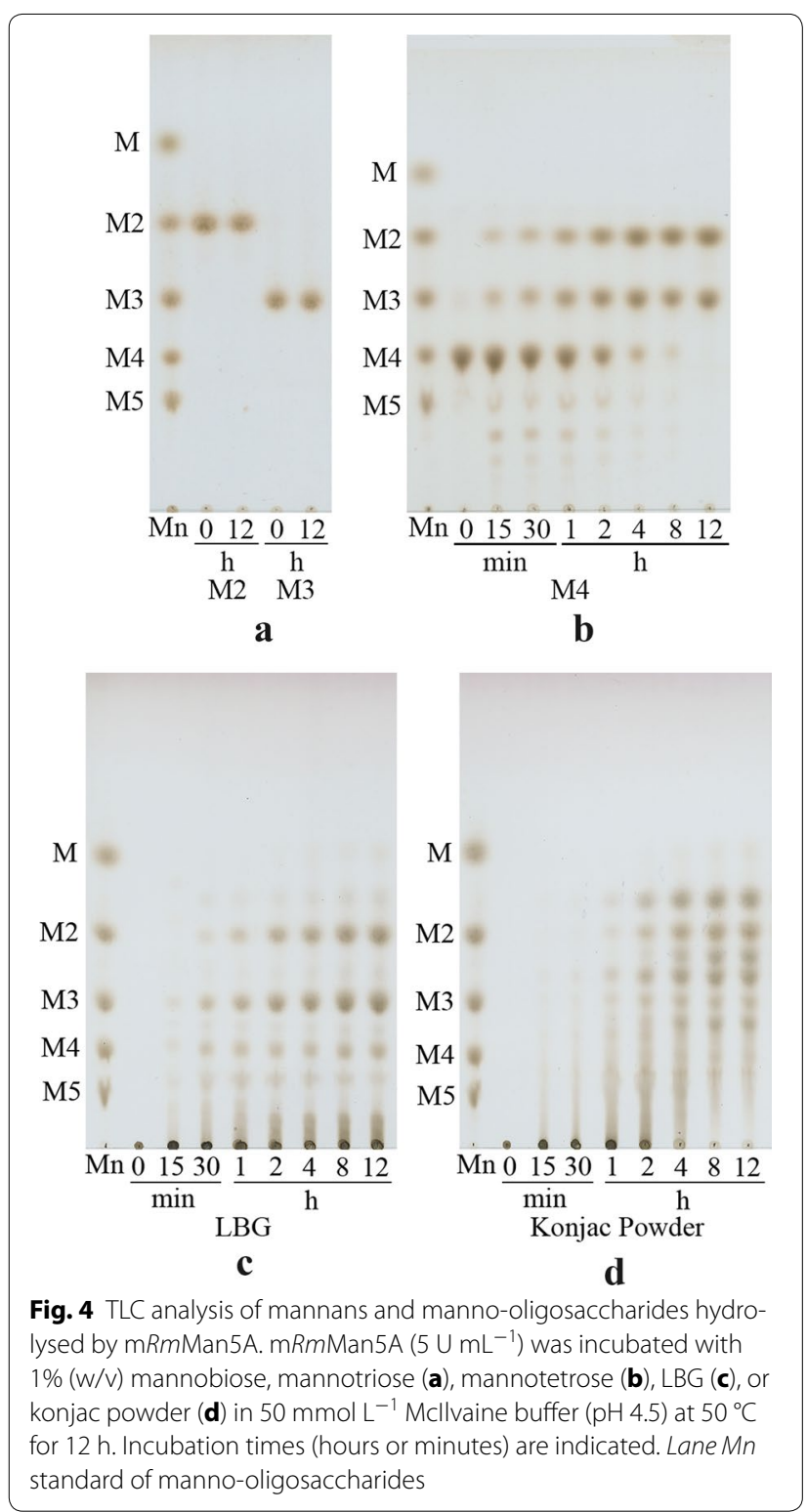

Tyr233His and Lys264Met shifted 1 and 1.5 units towards the acidic range, respectively (Fig. 5a). Meanwhile, their optimal temperatures both increased by $5{ }^{\circ} \mathrm{C}$ (Fig. $5 \mathrm{~b}$ ).
There was no change in optimal conditions between variant Asn343Ser and RmMan5A (Fig. 5). Subsequently, the variant with double mutants (Tyr233His/Lys264Met) was generated and characterized. Its maximal activity was found in optimal condition of $\mathrm{pH} 4.5$ and $65{ }^{\circ} \mathrm{C}$ (Fig. 5), which was same as $\mathrm{m} R m \mathrm{Man} 5 \mathrm{~A}$. Moreover, the specific activities of four variants $(9834.6,10,139.5,10,849.1$, and $9942.8 \mathrm{U} \mathrm{mg}^{-1}$, respectively) showed no significant difference between $R m M a n 5 \mathrm{~A}$ and $\mathrm{m} R m \mathrm{man} 5 \mathrm{~A}$ at the optimal condition of each enzyme.

\section{Structure analysis of mutant enzyme}

As a GH family $5 \beta$-mannanase, $R m$ Man $5 \mathrm{~A}$ shares less than $40 \%$ of amino acid identities with other structurally determined $\beta$-mannanases and its overall structure exhibits a classical $(\beta / \alpha)_{8}$-TIM barrel fold [31]. According to the structure of $R m M a n 5 \mathrm{~A}$, all three substitutions (Tyr233His, Lys264Met, and Asn343Ser) were located on the surface of enzyme (Fig. 6a). In RmMan5A, the distances between Tyr233, Lys264, and the catalytic amino acids were 16 and $14 \AA$, respectively. In contrast, the residue Asn343 was much far away from the catalytic site (27-30 ̊̊). Moreover, charge distribution of the right area of catalytic groove was transferred after directed evolution (Fig. 6b).

\section{Site-saturation mutagenesis}

To further investigate the effect of residues Tyr233 and Lys264 on the enzymatic properties of RmMan5A, two SSM libraries at residues Tyr233 and Lys264 were generated. All twenty variants of each position were collected after sequencing about 100 clones of each library. Optimal $\mathrm{pH}$ and temperatures of all variants were measured (Additional file 1: Table S2). Among the twenty variants of Tyr233, none of the variants showed changes in optimal conditions except variant Tyr233His ( $\mathrm{pH} 6.0$ and $\left.60{ }^{\circ} \mathrm{C}\right)$, Tyr233Arg $\left(\mathrm{pH} 6.5\right.$ and $\left.55^{\circ} \mathrm{C}\right)$, and Tyr233Ile (pH 6.5 and $55^{\circ} \mathrm{C}$ ). With respect to Lys264, many substitutions could decrease the $\mathrm{pH}$ optimum of RmMan5A, e.g., Lys264Gly, Lys264Val, Lys264Glu, and Lys264Asp, but none of them changed the optimal temperature of $R m M a n 5 A$. In contrast, variant Lys264Cys displayed the 

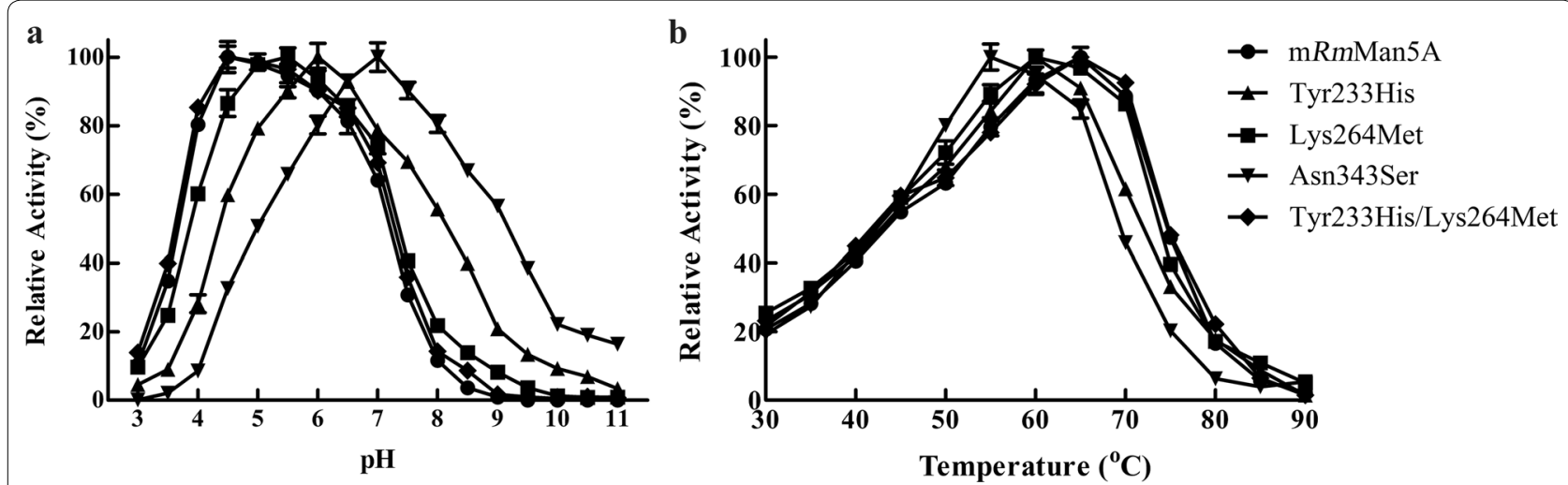

Fig. 5 Determination of optimal $\mathrm{pH}(\mathbf{a})$ and optimal temperature (b) of mRmMan5A and the variants derived using site-directed mutagenesis. The effect of $\mathrm{pH}$ on $\beta$-mannanase activity was determined in $50 \mathrm{mmol} \mathrm{L} \mathrm{L}^{-1}$ of different buffers at optimal temperature of each enzyme. For optimal temperature, activity was measured at different temperatures in 50 mmol $\mathrm{L}^{-1}$ Mcllvaine buffer (optimal pH of each enzyme). The specific activities of mRmMan5A (9671.4 U mg $\mathrm{mg}^{-1}$ ), variant Tyr233His (9834.6 U mg $\mathrm{mg}^{-1}$ ), variant Lys264Met $\left(10,139.5 \mathrm{U} \mathrm{mg}^{-1}\right)$, variant Asn343Ser $\left(10,849.1 \mathrm{U} \mathrm{mg}^{-1}\right)$, and variant Tyr233His/Lys264Met (9942.8 $\mathrm{U} \mathrm{mg}^{-1}$ ) were considered as 100\% in determinate the optimal pH and optimal temperature

lowest optimal $\mathrm{pH}(\mathrm{pH} 5.0$ instead of 7.0 for $\mathrm{RmMan} 5 \mathrm{~A}$ and $\mathrm{pH} 5.5$ for variant Lys264Met) and the highest optimal temperature $\left(60{ }^{\circ} \mathrm{C}\right.$, same with Lys264Met). To reveal the interplay of these two substitutions, the combinatorial mutagenesis was also generated. Variant Tyr233His/Lys264Cys showed the maximal activity at $\mathrm{pH} 4.5$ and $65^{\circ} \mathrm{C}$. Moreover, the specific activity of variant Tyr233His/Lys264Cys was $9878.8 \mathrm{U} \mathrm{mg}^{-1}$, which was not influenced after mutagenesis compared to $R m M$ Man5A and $\mathrm{mRmMan} 5 \mathrm{~A}$.

\section{Discussion}

Owing to the various biochemical properties, $\beta$-mannanases are widely used in many industrial applications, including biorefinery [7]. However, wild-type enzymes often show defects in biochemical properties, which limit their application in some industries [17]. Directed evolution is usually regarded as an effective means to improve the biochemical properties of enzyme, even when lack of structure information impedes the use of rational design [17]. The GH family $5 \beta$-mannanase (RmMan5A) from $R$. meihei CAU432 shows high specific activity and can hydrolyze many mannan substrates into manno-oligosaccharides, which makes this $\beta$-mannanase a suitable candidate for many industry applications [30]. However, its catalytic activity is significantly low in acidic and thermophilic conditions, which are common in biorefinery industry. In this study, to enhance its catalytic efficiency under acidic and thermophilic conditions and to improve its feasibility in biorefinery application, $R m$ Man5A was engineered by directed evolution.

After error-prone PCR and DNA shuffling, a mutant library was generated with a gene mutation frequency of $0.72 \%$, which is higher than the recommended mutation ratio $(2-5 \mathrm{bp} / \mathrm{kp})$ [27]. Therefore, about $70 \%$ clones of the mutant library were inactive clones. Eventually, one mutant $\beta$-mannanase (mRmMan5A) with three substitutions (Tyr233His, Lys264Met, and Asn343Ser) was discovered through two rounds of screening. Optimal $\mathrm{pH}$ of $\mathrm{mRmMan} 5 \mathrm{~A}$ was shifted from $\mathrm{pH} 7.0$ to 4.5 (Fig. 3a), and optimal temperature of $\mathrm{m} R m \mathrm{Man} 5 \mathrm{~A}$ was improved from 55 to $65{ }^{\circ} \mathrm{C}$ (Fig. 3c). After directed evolution, the optimal $\mathrm{pH}$ of $\mathrm{mRmMan} 5 \mathrm{~A}$ is much lower than those of many wild-type $\beta$-mannanases from Bacillus subtilis $(\mathrm{pH}$ 6.5) [32], Myceliophthora thermophila ( $\mathrm{pH}$ 6.0) [33], and Thermobifida fusca ( $\mathrm{pH}$ 8.0) [34]. Although the optimal condition of $\mathrm{mRmMan} 5 \mathrm{~A}$ still can not reach the level of several wild-type $\beta$-mannanases, such as rMan5P1 $\left(\mathrm{pH} 4.0,8{ }^{\circ} \mathrm{C}\right)[20], \operatorname{Man} 5 \mathrm{~A} 2\left(\mathrm{pH} 4.0,90^{\circ} \mathrm{C}\right)$ [21], and MAN-P ( $\left.\mathrm{pH} 4.5,80{ }^{\circ} \mathrm{C}\right)$ [35], the specific activities of these $\beta$-mannanases are significantly lower than that of $\mathrm{mRmMan} 5 \mathrm{~A}$ at their optimal conditions (Table 1 ). After directed evolution, the mutant inherited the specific activity of $R m$ Man5A, which is even higher than some wild-type $\beta$-mannanases with high specific activity, including the enzymes from $B$. subtilis $\left(7302 \mathrm{U} \mathrm{mg}^{-1}\right.$ towards LBG) [32] and Enterobacter sp. (8132 $\mathrm{U} \mathrm{mg}^{-1}$ towards LBG) [36]. In the optimal condition, the specific activity of $\mathrm{mRmMan} 5 \mathrm{~A}$ was significantly enhanced more than three times compared to RmMan5A (Table 1), and the catalytic efficiency was remarkably improved with $k_{\text {cat }} / K_{\mathrm{m}}$ value being at least $328 \%$ higher than that of the wild-type (Table 2). These changes indicate that the catalytic activity of $R m$ Man5A has been enhanced in acidic and thermophilic conditions. Moreover, there was no change between the $K_{\mathrm{m}}$ values of $\mathrm{mRmMan} 5 \mathrm{~A}$ and $R m M a n 5 \mathrm{~A}$, indicating that the affinity for substrates is not influenced by directed evolution. In this study, main 

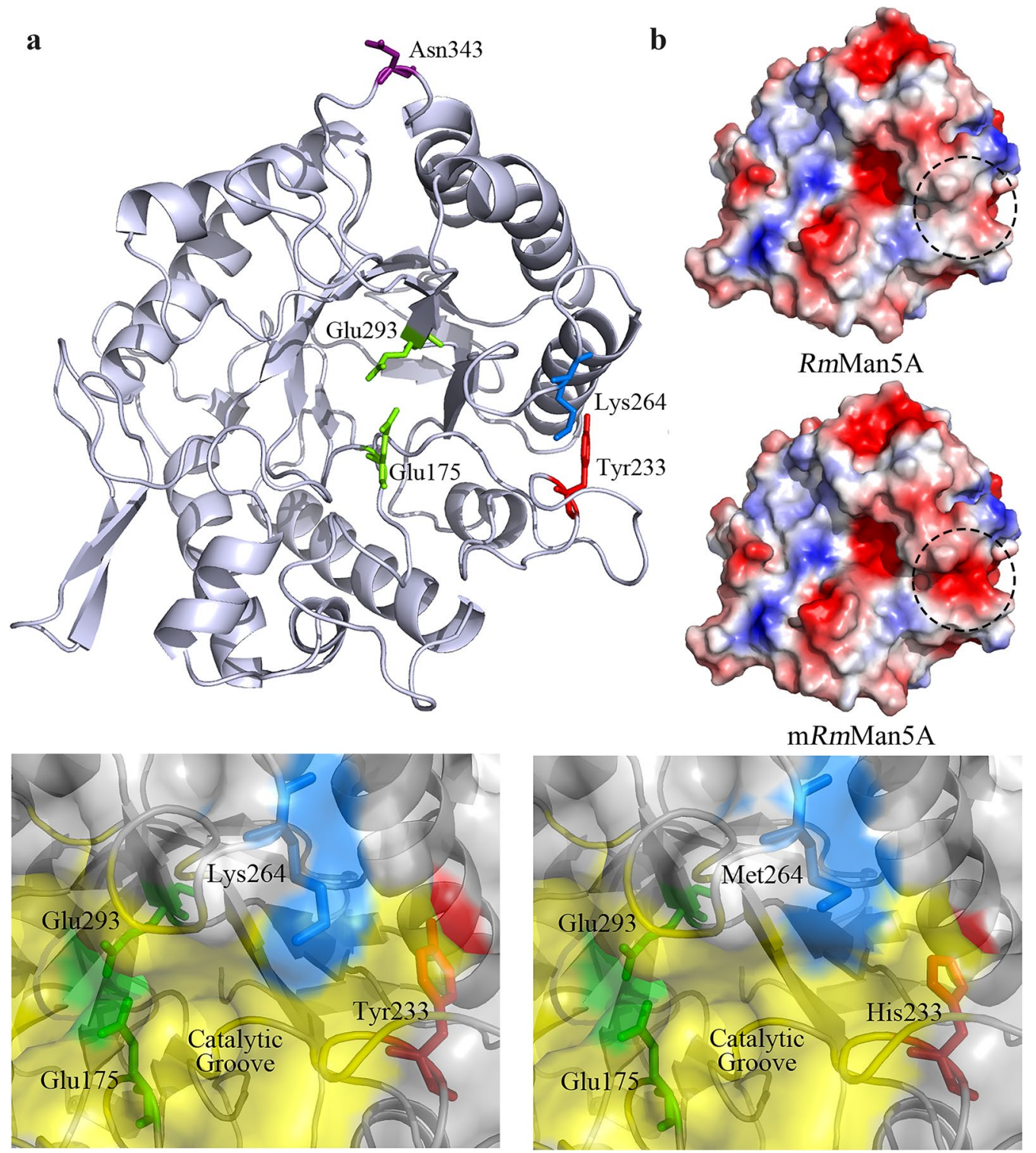

c

d

Fig. 6 Localization of the three substitutions, surface view, and charge distribution in RmMan5A and mRmMan5A. a Localization of three residues (Tyr233, Lys264, and Asn343) and active site (Glu175 and Glu293) in RmMan5A. b The protein surface charge of RmMan5A and mRmMan5A. The most negative and most positive electrostatic potentials are indicated by red and blue, respectively. c The location of Tyr 233 and Lys 264 in RmMan5A before mutation. d The location of His233 and Met264 in mRmMan5A after mutation. Tyr233, Lys264, and Asn343 were shown in red, blue, and purple, respectively. The active site and catalytic groove were colored in green and yellow, respectively

biochemical properties of $\mathrm{m} R m \mathrm{Man} 5 \mathrm{~A}$, namely the optimal $\mathrm{pH}$ and temperature, were enhanced in one mutant at the same time. Similar phenomenon is only observed in few enzymes, such as feruloyl esterase and xylanase [37-39]. Furthermore, $\mathrm{m} R m \mathrm{Man} 5 \mathrm{~A}$ also inherited the excellent hydrolysis property of RmMan5A. When LBG and konjac powders were hydrolyzed by $\mathrm{m} R m \mathrm{Man} 5 \mathrm{~A}$, the polysaccharides were rapidly degraded into M2, M3, and other oligosaccharides (Fig. 4). When linear mannan was hydrolyzed by $\mathrm{mRmMan} 5 \mathrm{~A}$ at $\mathrm{pH} 4.5$ and $50{ }^{\circ} \mathrm{C}$ for $24 \mathrm{~h}$, the concentration of M2 and M3 yielded was much higher than the values obtained by RmMan5A (Additional file 1: Figure S2). This indicates that the improved biochemical property is valuable to enhance the application of $\mathrm{mRmMan} 5 \mathrm{~A}$ in mannan degradation in acidic and thermophilic conditions. The comprehensive properties 
obtained by directed evolution make $\mathrm{m} R m \operatorname{Man} 5 \mathrm{~A}$ a potential candidate for biorefinery of mannan biomasses, which is conducted in acidic and thermal environments.

In general, most key mutations which lead to the evolution of properties, such as catalytic efficiency, specific activity, and optimal condition, are located on the surface of enzyme [24, 26, 40]. Conforming to this, all three substitutions (Tyr233His, Lys264Met, and Asn343Ser) were situated on the surface of RmMan5A (Fig. 6a). To determine the influence of each amino acid substitution, three variants (Tyr233His, Lys264Met, and Asn343Ser) were generated by SDM. Among these variants, variant Tyr233His displayed noticeable changes with the optimal condition of pH 6.0 and $60{ }^{\circ} \mathrm{C}$ (Fig. 5). In RmMan5A, Tyr233 with high hydrophobic feature was located near the catalytic groove, and its hydrophobic side chain pointed to the $\alpha$-helix six (Fig. 6c). It is generally assumed that hydrophobic residues are not favorable at similar sites for protein stability [41, 42]. In variant Tyr233His, His with a hydrophilic side chain was inserted by substitution Tyr233His (Fig. 6d). This replacement increases the hydrophilic nature of the surface, and was found to stabilize the protein when compared with RmMan5A. Moreover, the number of polar residues (Asn, His, and Gln) in acidic $\beta$-mannanases is normally more than that in alkaline $\beta$-mannanases [16]. This might be another reason for the change of variant Tyr233His. Variant Lys264Met was another significant variant, which showed acidic shift by 1.5 units of optimal $\mathrm{pH}$ and increase by $5{ }^{\circ} \mathrm{C}$ of optimal temperature (Fig. 5). In RmMan5A, the distance between Lys264 and the catalytic site was $14 \AA$. Normally, the ionizable residues in the vicinity of catalytic residues have the ability to affect the $\mathrm{pH}$-dependent activity of enzyme or even the catalysis process to some extent $[26,43]$. In variant Lys264Met, the positively charged residue Lys264 on the edge of catalytic groove was substituted by a non-polar residue Met (Fig. 6d). This substitution affects the local charge balance near the catalysis groove and improves the catalytic efficiency of mutant in acidic condition. In contrast, Asn343 was much further (27-30 $\AA$ ) from the catalytic amino acids. Thus, variant Asn343Ser showed imperceptible changes compared to RmMan5A (Fig. 5). To determine the interactive effect of Tyr233His and Lys264Met, the variant with double mutations was generated. Optimal conditions of variant Tyr233His/Lys264Met were same as mRmMan5A (Fig. 5), which means that the combination of Tyr233His and Lys264Met is the major reason for property evolution of $\mathrm{mRmMan} 5 \mathrm{~A}$. According to the analysis of protein surface charge (Fig. 6b), weak negative charge in the right area of catalytic groove of $R m M a n 5 \mathrm{~A}$ was transformed into strong negative charge after directed evolution. This change mainly caused by
Tyr233His and Lys264Met. In general, the charge change of catalytic groove can impact on the substrate acceptance in the catalytic groove $[40,42]$. However, the $K_{\mathrm{m}}$ values of $\mathrm{mRmMan} 5 \mathrm{~A}$ did not show significant change comparing to that of $R m M a n 5 \mathrm{~A}$ after directed evolution. This means that the substrate acceptance of $\mathrm{m} R m \mathrm{Man} 5 \mathrm{~A}$ is not influenced by the charge change. The improvement of catalytic efficiencies $\left(k_{\text {cat }} / K_{\mathrm{m}}\right)$ in acidic and thermophilic condition is originated from the increase of $V_{\max }$ and $k_{\text {cat }}$ of $\mathrm{m} R m$ Man5A. This may be similar reason for the catalytic efficiency increase of many other enzymes such as phytase and protease [44, 45]. Moreover, SSM on residues Tyr233 and Lys264 of RmMan5A were performed. Similar to the result of SDM, residue Tyr233 showed less influence on the enzymatic properties. Only variant Tyr233His showed noticeable changes in optimal conditions. The substitution of Lys 264 is easier to affect the enzymatic properties than that of Tyr233. Among the twenty variants, four variants (Lys264Gly, Lys264Val, Lys264Glu, and Lys264Asp) have acidic shift in pH optima, and the variant Lys264Cys displayed significant change in both of optimal $\mathrm{pH}$ and temperature. The $\mathrm{pH}$ optimum of variant Lys264Cys is even lower than variant Lys264Met. However, the variant with double mutant (Tyr233His/ Lys264Cys) did not exhibit any improvement in optimal conditions compared to $\mathrm{mRmMan} 5 \mathrm{~A}$. According to the result of sequence alignment (Fig. 1), the residues Try233 and Lys264 are entirely or partly conserved in GH family $5 \beta$-mannanases. Therefore, these results can provide some basis for the engineering and modification of $\mathrm{GH}$ family $5 \beta$-mannanase in future.

\section{Conclusions}

A $\beta$-mannanase (RmMan5A) from $R$. meihei CAU432 was engineered by directed evolution. The mutant $\beta$-mannanase ( $\mathrm{m} R m \mathrm{man} 5 \mathrm{~A})$ showed an improved catalytic activity under acidic and thermophilic conditions without any significant change in other properties of $R m M a n 5 A$. mRmMan5A can be a suitable candidate for biorefinery of mannan biomasses, which commonly needs acidic and thermophilic environment. Two substitutions (Tyr233His and Lys264Met) were the main reason for the property evolution of $\mathrm{m} R m \mathrm{Man} 5 \mathrm{~A}$. Some new information on the structure-function relationship of $\beta$-mannanase was provided for the engineering and modification of GH family $5 \beta$-mannanase.

\section{Methods}

\section{Vectors and chemicals}

The pET28a-RmMan5A was constructed as described previously [30]. E. coli DH5 $\alpha$ and BL21 (DE3) were used for plasmids propagating and gene expression, respectively. Vector pET28a $(+)$ was obtained from Novagen 
(Madison, WI, USA). Chelating Sepharose (Ni-IDA) resin matrix was purchased from GE Life Sciences (Pittsburgh, PA, USA). LBG and guar gum were obtained from Sigma (St. Louis, MO, USA). Unless otherwise stated, all other chemicals were of analytical grade.

\section{Generation of the mutant library}

DNA shuffling mutant library was generated according to previous description with slight modifications [40]. Random libraries were constructed by error-prone PCR using pET28a-RmMan5A as template with primers RmMan5AF and RmMan5AR (Additional file 1: Table S1). The amplification products were digested by DNase I according to Lorimer and Pastan [46]. The full-length gene was reassembled by self-reassembling PCR using the purified DNA fragments. After digestion with BamHI and XhoI, PCR products were ligated with plasmid pET-28a (+). The resulting recombinant plasmids were transformed into $E$. coli BL21 (DE3) to build the mutant library.

\section{Screening of the mutant library}

In first round of selection, Congo red plate assay was used to screen the forward mutants. All mutants were spread on a Luria-Bertani (LB) plate, containing $50 \mu \mathrm{g} \mathrm{mL}$ kanamycin, and incubated at $37^{\circ} \mathrm{C}$ for 1 day. Every single colony was then transferred into the screening LB plates using sterile toothpick, which contained $50 \mathrm{mmol} \mathrm{L}^{-1}$ McIlvaine buffer (pH 5.0), $1 \mathrm{mmol} \mathrm{L}^{-1}$ IPTG, $0.5 \%$ (w/v) LBG, and $50 \mu \mathrm{g} \mathrm{mL}^{-1}$ kanamycin. As a control, the wildtype $R m$ Man5A was inoculated on each plate. After incubation at $37^{\circ} \mathrm{C}$ for $24 \mathrm{~h}$, the cells were lysed at $60{ }^{\circ} \mathrm{C}$ for $1 \mathrm{~h}$. Subsequently, all plates were stained by $0.1 \%(\mathrm{w} / \mathrm{v})$ Congo red and washed by $1 \mathrm{~mol} \mathrm{~L}^{-1} \mathrm{NaCl}$ until the halos appeared. The size of halos was measured and compared to the control. Transformants with similar or larger halo were selected for next selection. In second round of selection, the optimal conditions of selected transformant were measured, and the mutants with change on optimal conditions were then sequenced.

\section{Expression and purification of the mutants}

The enzyme was expressed and purified as previously described [30]. Briefly, after induction with $1 \%(\mathrm{w} / \mathrm{v})$ lactose for $20 \mathrm{~h}$, the cells were harvested and then disrupted by sonication. The crude enzyme obtained through centrifugation was applied to a Ni-IDA agarose resin column and then purified by fast protein liquid chromatography (FPLC, ÄKTA purifier, GE healthcare). Impurities were washed off with five column volumes of buffer A $\left(20 \mathrm{mmol} \mathrm{L}^{-1}\right.$ phosphate, $300 \mathrm{mmol} \mathrm{L}^{-1} \mathrm{NaCl}$, and $20 \mathrm{mmol} \mathrm{L}^{-1}$ imidazole at $\mathrm{pH} 8.0$ ) and buffer $\mathrm{B}$
(20 mmol L $\mathrm{m}^{-1}$ phosphate buffer, $300 \mathrm{mmol} \mathrm{L}^{-1} \mathrm{NaCl}$, and $50 \mathrm{mmol} \mathrm{L}^{-1}$ imidazole at $\mathrm{pH}$ 8.0). The bound protein was then eluted with buffer $\mathrm{C}\left(20 \mathrm{mmol} \mathrm{L}^{-1}\right.$ phosphate buffer, $300 \mathrm{mmol} \mathrm{L}^{-1} \mathrm{NaCl}$, and $200 \mathrm{mmol} \mathrm{L}^{-1}$ imidazole at $\mathrm{pH}$ 8.0). Fractions showing $\beta$-mannanase activity were pooled and concentrated by ultrafiltration. SDS-PAGE was executed to analyze the purity and molecular mass on a $12.5 \%$ gel [47].

\section{Enzyme assay and protein concentration}

To determine the $\beta$-mannanase activity, the amount of reducing sugar was determined using 3,5-dinitrosalicylic acid (DNS) method [48]. A total of $0.1 \mathrm{~mL}$ of diluted enzyme was mixed with $0.9 \mathrm{~mL}$ of LBG solution $(0.5 \%$, $\mathrm{w} / \mathrm{v}, 50 \mathrm{mmol} \mathrm{L}^{-1}$ Mcllvaine buffer, $\mathrm{pH} 4.5$ ) and incubated at $65{ }^{\circ} \mathrm{C}$ for $10 \mathrm{~min}$. After addition with $1 \mathrm{~mL}$ of DNS, the mixture was boiled for $15 \mathrm{~min}$, and immediately added with $1 \mathrm{~mL}$ of $40 \%(\mathrm{w} / \mathrm{v})$ sodium potassium tartarate. The absorbance was measured at $540 \mathrm{~nm}$ and mannose was used as standard for reducing sugar content calculation. One unit of $\beta$-mannanase activity was defined as the amount of enzyme that liberated $1 \mu \mathrm{mol}$ of reducing sugars per minute under the conditions described. The concentration of protein was measured by Lowry's method using bovine serum albumin as standard [49].

\section{Biochemical properties and kinetic parameters}

Optimal $\mathrm{pH}$ of enzyme was determined in $50 \mathrm{mmol} \mathrm{L}^{-1}$ different buffers with $\mathrm{pH}$ ranging from 3.0 to 11.0. The buffers included Mcllvaine ( $\mathrm{pH} 3.0-7.0)$, acetate ( $\mathrm{pH} 4.0-6.0)$, phosphate $(\mathrm{pH}$ 6.0-8.0), tris (hydroxymethyl) aminomethane- $\mathrm{HCl}$ (Tris- $\mathrm{HCl}$ ) (pH 7.0-9.0), 2-(cyclohexylamino) ethanesulfonic acid (CHES) $(\mathrm{pH}$ 8.0-10.0), and glycine- $\mathrm{NaOH}$ (pH 9.5-11.0). To measure $\mathrm{pH}$ stability, enzyme samples were incubated in above buffers at $50{ }^{\circ} \mathrm{C}$ for $30 \mathrm{~min}$, and the residual activities were determined by standard assay. Optimal temperature was assessed in $50 \mathrm{mmol} \mathrm{L}^{-1}$ McIlvaine buffer ( $\mathrm{pH} 4.5$ ) at a temperature range of $30-90{ }^{\circ} \mathrm{C}$. Effect of temperature on enzyme stability was examined by determining the residual activity after incubating at different temperatures for $30 \mathrm{~min}$.

Substrate specifities of $\beta$-mannanase towards $0.5 \%$ $(\mathrm{w} / \mathrm{v})$ of LBG, konjac powder, and guar gum were measured at $65^{\circ} \mathrm{C}$ and $\mathrm{pH} 4.5$. Kinetic parameters toward LBG and guar gum were determined at the substrates concentration ranges of 1-7 and 3-14 $\mathrm{mg} \mathrm{mL}^{-1}$, respectively, at $65^{\circ} \mathrm{C}$ in $50 \mathrm{mmol} \mathrm{L}^{-1}$ Mcllvaine buffer (pH 4.5) for $5 \mathrm{~min}$ using DNS method. The value of $K_{\mathrm{m}}$ and $V_{\max }$ was calculated using the software GraFit. All activity assays were performed in triplicate. 


\section{Hydrolysis property}

Hydrolysis properties of $\mathrm{m} R m \mathrm{Man} 5 \mathrm{~A}$ towards various manno-oligosaccharides and mannans were analyzed as given below. A total of $1 \mathrm{~mL}$ of reaction mixture containing $1 \%(w / v)$ of LBG, konjac power, M2, M3, or M4 and $5 \mathrm{U}$ of $\mathrm{mRmMan} 5 \mathrm{~A}$ was incubated in $50 \mathrm{mmol} \mathrm{L}^{-1}$ McIlvaine buffer ( $\mathrm{pH} 4.5)$ at $50{ }^{\circ} \mathrm{C}$ for $12 \mathrm{~h}$. Samples of different time points were withdrawn and boiled for $5 \mathrm{~min}$. After centrifugation at $10,000 \times g$ for $3 \mathrm{~min}$, all samples were analyzed by thin-layer chromatography (TLC). The silica gel plate (Merck Silica Gel 60 F254, Darmstadt, Germany) loaded with samples was developed twice in a solvent system, containing n-butylalcohol:acetic acid:water $(2: 1: 1, \mathrm{v} / \mathrm{v})$. After immersing in the solution (methanol:sulfuric acid 95:5, v/v), the plate was heated in an oven to visualize the saccharides. Mixtures of M-M4, and mannopentaose (M5) were used as standards.

\section{Hydrolysis of linear mannan}

$R m$ Man5A and $\mathrm{m} R m$ Man5A were subjected to hydrolyze linear mannan. Briefly, $1.0 \mathrm{~g}$ of linear mannan was mixed with $20 \mathrm{~mL} 50 \mathrm{mmol} \mathrm{L}^{-1}$ McIlvaine buffer ( $\mathrm{pH}$ 4.5). Then the $\beta$-mannanase was added in a proportion of $50 \mathrm{U} \mathrm{mL}^{-1}$ and enzymatic reaction was performed at $50{ }^{\circ} \mathrm{C}$ and $200 \mathrm{rpm}$ for $24 \mathrm{~h}$. Samples of different time points were withdrawn and boiled for $5 \mathrm{~min}$. All samples were analyzed by high performance liquid chromatography (HPLC, Waters Alliance 2695 system) equipped with evaporative light-scattering detector (ELSD, Waters 2424 HPLC ELS). The separation of manno-oligosaccharides was completed on a Sugar KS-802 column $(7.8 \times 300 \mathrm{~mm}$, Shodex) with ultrapure water as mobile phase at a flow rate of $0.8 \mathrm{~mL} \mathrm{~min}{ }^{-1}$. Column temperature was maintained at $80^{\circ} \mathrm{C}$. Nitrogen was used as nebulising gas for ELSD at a flow rate $2.0 \mathrm{~L} \mathrm{~min}^{-1}$ and the temperature of drift tube was fixed at $50{ }^{\circ} \mathrm{C}$. M-M 5 were used as standards.

\section{Site-directed mutagenesis}

The overlap extension PCR method was used to perform SDM as previously described [24]. The plasmid pET28aRmMan5A was used as template and the primers were designed according to three substitutions (Additional file 1: Table S1). The products were ligated to plasmid pET-28a (+) after digestion with BamHI and XhoI. Then the plasmids harboring the desired mutations were transformed into E. coli BL21 (DE3) for expression.

\section{Site-saturation mutagenesis}

SSM on residues Try233 and Lys264 of RmMan5A was carried out as described in previous literature [50]. The plasmid pET28a-RmMan5A was used as template and the primers were designed using NNK degeneracy (Additional file 1: Table S1). The PCR products were digested by $D p n \mathrm{I}$ overnight at $37{ }^{\circ} \mathrm{C}$, and the mixture was then incubated at $80^{\circ} \mathrm{C}$ for $20 \mathrm{~min}$ to inactivate $D p n$ I. After purification, the products were transformed into E. coli BL21 (DE3) competent cells by electroporation transformation. The transformants were subsequently cultured on LB plate at $37^{\circ} \mathrm{C}$ overnight. The DNA sequences of single colonies were sequenced to collect all 20 variants of each position.

\section{Structure analysis of mutant enzyme}

The 3D structure of RmMan5A had been reported in our previous work (PBD ID: 4qp0) [31]. Visualization and analysis of structural model were performed using PyMOL software.

\section{Additional file}

Additional file 1: Table S1. Oligonucleotide primers used for plasmid construction, site-directed mutagenesis, and site-saturation mutagenesis. Table S2. Optimal pH and temperature of twenty variants of Tyr233 and Lys264. Figure S1. The summary of screening strategy and mutant selection. Figure S2. HPLC analysis of linear mannan hydrolyzed by $\mathrm{m} R \mathrm{~m}$ Man5A and RmMan5A

\section{Abbreviations \\ GH: glycoside hydrolase; error-prone PCR: error-prone polymerase chain reaction; SDM: site-directed mutagenesis; SSM: site-saturation mutagenesis; Ni-IDA: Ni-iminodiacetic acid; SDS-PAGE: sodium dodecyl sulfate polyacrylamide gel electrophoresis; LBG: locust bean gum; M: mannose; M2: mannobiose; M3: mannotriose; M4: mannotetrose; M5: mannopentaose; DNS: 3,5-dinitrosalicylic acid; Tris: tris (hydroxymethyl) aminomethane; CHES: 2-(cyclohexylamino) ethanesulfonic acid; TLC: thin-layer chromatography.}

\section{Authors' contributions}

YXL designed and conducted most of the experiments, analyzed the results, and wrote the paper. PY performed direct evolution, site-directed mutagenesis, and site-saturation mutagenesis. ZQ performed preliminary structure analysis of the mutants. XQL participated in the biochemical experiments of the mutants. QJY and ZQJ participated in the design, coordination, and data analysis of the study and corrected the manuscript. All authors read and approved the final manuscript.

\section{Acknowledgements}

This work was supported partially by State key research and development plan "modern food processing and food storage and transportation technology and equipment (No. 2016YFD0400804), the Key Program of National Natural Science Foundation of China (No. 31630096), National Science Fund for Distinguished Young Scholars (No. 31325021), and Program for Changjiang Scholars and Innovative Research Team in University (No. IRT1293).

\section{Competing interests}

The authors declare that they have no competing interests.

\section{Consent for publication}

All authors have approved the consent for publication.

\section{Ethical approval and consent to participate}

The work described has not been submitted elsewhere for publication, in whole or in part, and all authors listed carry out the data analysis and manuscript writing. This article does not contain any studies with animals performed by any of the authors. 


\section{Publisher's Note}

Springer Nature remains neutral with regard to jurisdictional claims in published maps and institutional affiliations.

Received: 24 January 2017 Accepted: 26 May 2017

Published online: 02 June 2017

\section{References}

1. Shukor H, Abdeshahian P, Al-Shorgani NKN, Hamid AA, Rahman NA, Kalil MS. Saccharification of polysaccharide content of palm kernel cake using enzymatic catalysis for production of biobutanol in acetone-butanolethanol fermentation. Bioresour Technol. 2016;202:206-13.

2. Ragauskas AJ, Williams CK, Davison BH, Britovsek G, Cairney J, Eckert CA, Frederick WJ, Hallett JP, Leak DJ, Liotta CL, Mielenz JR, Murphy R, Templer $\mathrm{R}$, Tschaplinski T. The path forward for biofuels and biomaterials. Science. 2006;311:484-9.

3. van Zyl WH, Rose SH, Trollope K, Görgens JF. Fungal $\beta$-mannanases: mannan hydrolysis, heterologous production and biotechnological applications. Process Biochem. 2010;45:1203-13.

4. Malgas S, van Dyk JS, Pletschke BI. A review of the enzymatic hydrolysis of mannans and synergistic interactions between $\beta$-mannanase, $\beta$-mannosidase and a-galactosidase. World J Microbiol Biotechnol. 2015:31:1167-75.

5. Eom I, Yu J, Jung C, Hong K. Efficient ethanol production from dried oil palm trunk treated by hydrothermolysis and subsequent enzymatic hydrolysis. Biotechnol Biofuels. 2015;8:83.

6. Moreira LRS, Filho EXF. An overview of mannan structure and mannandegrading enzyme systems. Appl Microbiol Biotechnol. 2008;79:165-78

7. Chauhan PS, Puri N, Sharma P, Gupta N. Mannanases: microbial sources, production, properties and potential biotechnological applications. Appl Microbiol Biotechnol. 2012;93:1817-30.

8. Yang M, Cai J, Wang CG, Du X, Lin JG. Characterization of endo- $\beta$ mannanase from Enterobacter ludwigii MY271 and application in pulp industry. Bioprocess Biosyst Eng. 2017;40:35-43.

9. Zhang YL, Ju JS, Peng H, Gao F, Zhou C, Zeng Y, Xue YF, Li Y, Henrissat B, Gao GF, Ma YH. Biochemical and structural characterization of the intracellular mannanase AaManA of Alicyclobacillus acidocaldarius reveals a novel glycoside hydrolase family belonging to Clan GH-A. J Biol Chem. 2008;283:31551-8.

10. Chai SY, Bakar FDA, Mahadi NM, Murad AMA. A thermotolerant endo1,4- $\beta$-mannanase from Trichoderma virens UKM1: cloning, recombinant expression and characterization. J Mol Catal B Enzym. 2016;125:49-57.

11. Shimizu M, Kaneko Y, Ishihara S, Mochizuki M, Sakai K, Yamada M, Murata S, Itoh E, Yamamoto T, Sugimura Y, Hirano T, Takaya N, Kobayashi T, Kato M. Novel $\beta-1,4-m a n n a n a s e$ belonging to a new glycoside hydrolase family in Aspergillus nidulans. J Biol Chem. 2015;290:27914-27.

12. Jin $Y$, Petricevic M, John A, Raich L, Jenkins H, Portela De Souza L, Cuskin F, Gilbert HJ, Rovira C, Goddard-Borger ED, Williams SJ, Davies GJA. $\beta$-mannanase with a lysozyme-like fold and a novel molecular catalytic mechanism. ACS Central Science. 2016;2:896-903.

13. Pradeep GC, Cho SS, Choi YH, Choi YS, Jee JP, Seong CN, Yoo JC. An extremely alkaline mannanase from Streptomyces sp. CS428 hydrolyzes galactomannan producing series of mannooligosaccharides. World J Microbiol Biotechnol. 2016:32:84.

14. Dhawan S, Kaur J. Microbial mannanases: an overview of production and applications. Crit Rev Biotechnol. 2007;27:197-216.

15. Aspeborg H, Coutinho PM, Wang Y, Brumer H, Henrissat B. Evolution, substrate specificity and subfamily classification of glycoside hydrolase family 5 (GH5). BMC Evol Biol. 2012;12:186.

16. Zhao YJ, Zhang YH, Cao Y, Qi JX, Mao LW, Xue YF, Gao F, Peng H, Wang XW, Gao GF, Ma YH. Structural analysis of alkaline $\beta$-mannanase from alkaliphilic Bacillus sp. N16-5: implications for adaptation to alkaline conditions. PLOS ONE. 2011;6:e14608.

17. Porter JL, Rusli RA, Ollis DL. Directed evolution of enzymes for industrial biocatalysis. ChemBioChem. 2016;17:197-203.

18. Chiesa S, Gnansounou E. Use of empty fruit bunches from the oil palm for bioethanol production: a thorough comparison between dilute acid and dilute alkali pretreatment. Bioresour Technol. 2014;159:355-64.
19. Medina JDC, Woiciechowski A, Filho AZ, Nigam PS, Ramos LP, Soccol CR. Steam explosion pretreatment of oil palm empty fruit bunches (EFB) using autocatalytic hydrolysis: a biorefinery approach. Bioresour Technol. 2016;199:173-80.

20. Yang $H$, Shi PJ, Lu HQ, Wang HM, Luo HY, Huang HQ, Yang PL, Yao B. A thermophilic $\beta$-mannanase from Neosartorya fischeri $\mathrm{P} 1$ with broad $\mathrm{pH}$ stability and significant hydrolysis ability of various mannan polymers. Food Chem. 2015;173:283-9.

21. Wang CH, Luo HY, Niu CF, Shi PJ, Huang HQ, Meng K, Bai YG, Wang K, Hua $\mathrm{HF}$, Yao B. Biochemical characterization of a thermophilic $\beta$-mannanase from Talaromyces leycettanus JCM12802 with high specific activity. Appl Microbiol Biotechnol. 2015;99:1217-28.

22. Wang M, Si T, Zhao HM. Biocatalyst development by directed evolution. Bioresour Technol. 2012;115:117-25.

23. Larue K, Melgar M, Martin VJJ. Directed evolution of a fungal $\beta$-glucosidase in Saccharomyces cerevisiae. Biotechnol Biofuels. 2016;9:52.

24. Trollope KM, Görgens JF, Volschenk H. Semirational directed evolution of loop regions in Aspergillus japonicus $\beta$-fructofuranosidase for improved fructooligosaccharide production. Appl Environ Microbiol. 2015;81:7319-29.

25. Zhou C, Ye JT, Xue YF, Ma YH. Directed evolution and structural analysis of alkaline pectate lyase from the alkaliphilic bacterium Bacillus sp. strain N16-5 to improve its thermostability for efficient ramie degumming. Appl Environ Microbiol. 2015;81:5714-23.

26. Wang J, Zhang QY, Huang ZQ, Liu ZD. Directed evolution of a family 26 glycoside hydrolase: endo- $\beta-1,4-m a n n a n a s e$ from Pantoea agglomerans A021. J Biotechnol. 2013;167:350-6.

27. Couturier M, Feliu J, Bozonnet S, Roussel A, Berrin J. Molecular engineering of fungal GH5 and GH26 $\beta$ - $(1,4)$-mannanases toward improvement of enzyme activity. PLoS ONE. 2013;8:e7980011.

28. Zhou P, Chen Z, Yan QJ, Yang SQ, Hilgenfeld R, Jiang ZQ. The structure of a glycoside hydrolase family 81 endo- $\beta-1,3-$ glucanase. Acta Crystallogr Sect D Biol Crystallogr. 2013;69:2027-38.

29. Tang YB, Yang SQ, Yan QJ, Zhou P, Cui J, Jiang ZQ. Purification and characterization of a novel $\beta-1,3-1,4$-glucanase (lichenase) from thermophilic Rhizomucor miehei with high specific activity and its gene sequence. J Agric Food Chem. 2012;60:2354-61.

30. Katrolia P, Yan QJ, Zhang P, Zhou P, Yang SQ, Jiang ZQ. Gene cloning and enzymatic characterization of an alkali-tolerant endo-1,4- $\beta$-mannanase from Rhizomucor miehei. J Agric Food Chem. 2013;61:394-401.

31. Zhou P, Liu Y, Yan QJ, Chen ZZ, Qin Z, Jiang ZQ. Structural insights into the substrate specificity and transglycosylation activity of a fungal glycoside hydrolase family $5 \beta$-mannosidase. Acta Crystallogr Sect D: Biol Crystallogr. 2014;70:2970-82.

32. Liu HX, Gong JS, Li H, Lu ZM, Li H, Qian JY, Xu ZH, Shi JS. Biochemical characterization and cloning of an endo-1,4- $\beta$-mannanase from Bacillus subtilis YH12 with unusually broad substrate profile. Process Biochem. 2015;50:712-21.

33. Katsimpouras C, Dimarogona M, Petropoulos P, Christakopoulos $P$, Topakas E. A thermostable GH26 endo- $\beta$-mannanase from Myceliophthora thermophila capable of enhancing lignocellulose degradation. Appl Microbiol Biotechnol. 2016;100:8385-97.

34. Chen $\mathrm{CY}$, Huang YC, Yang TY, Jian JY, Chen WL, Yang CH. Degradation of konjac glucomannan by Thermobifida fusca thermostable $\beta$-mannanase from yeast transformant. Int J Biol Macromol. 2016;82:1-6.

35. Yu S, Li ZZ, Wang YP, Chen WP, Fu L, Tang W, Chen C, Liu YY, Zhang X, Ma LX. High-level expression and characterization of a thermophilic ß-mannanase from Aspergillus niger in Pichia pastoris. Biotechnol Lett. 2015;37:1853-9.

36. You J, Liu JF, Yang SZ, Mu BZ. Low-temperature-active and salt-tolerant $\beta$-mannanase from a newly isolated Enterobacter sp. strain N18. J Biosci Bioeng. 2016;121:140-6.

37. Cao LC, Chen R, Xie W, Liu YH. Enhancing the thermostability of feruloyl esterase EstF27 by directed evolution and the underlying structural basis. J Agric Food Chem. 2015;63:8225-33.

38. Ruller R, Alponti J, Deliberto LA, Zanphorlin LM, Machado CB, Ward RJ. Concommitant adaptation of a $\mathrm{GH} 11$ xylanase by directed evolution to create an alkali-tolerant/thermophilic enzyme. Protein Eng Des Sel. 2014:27:255-62.

39. Xu X, Liu MQ, Huo WK, Dai XJ. Obtaining a mutant of Bacillus amyloliquefaciens xylanase A with improved catalytic activity by directed evolution. Enzym Microb Technol. 2016;86:59-66. 
40. Jia HY, Li YN, Liu YC, Yan QJ, Yang SQ, Jiang ZQ. Engineering a thermostable $\beta$-1,3-1,4-glucanase from Paecilomyces thermophila to improve catalytic efficiency at acidic pH. J Biotechnol. 2012;159:50-5.

41. Liu YH, Lu FP, Li Y, Wang JL, Gao C. Acid stabilization of Bacillus licheniformis alpha amylase through introduction of mutations. Appl Microbiol Biotechnol. 2008;80:795-803.

42. Zheng HC, Liu YH, Sun MZ, Han Y, Wang JL, Sun JS, Lu FP. Improvement of alkali stability and thermostability of Paenibacillus campinasensis Family-11 xylanase by directed evolution and site-directed mutagenesis. J Ind Microbiol Biotechnol. 2014;41:153-62.

43. Eijsink VGH, Gåseidnes S, Borchert TV, van den Burg B. Directed evolution of enzyme stability. Biomol Eng. 2005;22:21-30.

44. Chen WW, Ye LD, Guo F, Lv Y, Yu HW. Enhanced activity of an alkaline phytase from Bacillus subtilis 168 in acidic and neutral environments by directed evolution. Biochem Eng J. 2015;98:137-43.
45. Liu YH, Zhang T, Zhang ZM, Sun TY, Wang JL, Lu FP. Improvement of cold adaptation of Bacillus alcalophilus alkaline protease by directed evolution. J Mol Catal B Enzym. 2014;106:117-23.

46. Lorimer IA, Pastan I. Random recombination of antibody single chain FV sequences after fragmentation with DNasel in the presence of $\mathrm{Mn}^{2+}$. Nucleic Acids Res. 1995;23:3067-8.

47. Laemmli UK. Cleavage of structural proteins during the assembly of the head of bacteriophage T4. Nature. 1970;227:680-5.

48. Miller GL. Use of dinitrosalicylic acid reagent for determination of reducing sugars. Anal Chem. 1959;31:426-8.

49. Lowry $\mathrm{OH}$, Rosebrough NJ, Farr AL, Randall RJ. Protein measurement with the Folin phenol reagent. J Biol Chem. 1951;193:265-75.

50. Reetz MT, Carballeira JD. Iterative saturation mutagenesis (ISM) for rapid directed evolution of functional enzymes. Nat Protoc. 2007;2:891-903.

\section{Submit your next manuscript to BioMed Central and we will help you at every step:}

- We accept pre-submission inquiries

- Our selector tool helps you to find the most relevant journal

- We provide round the clock customer support

- Convenient online submission

- Thorough peer review

- Inclusion in PubMed and all major indexing services

- Maximum visibility for your research

Submit your manuscript at www.biomedcentral com/submit 